\title{
THE EFFECT OF WAGES AND WORK DISCIPLINE ON WORK PRODUCTIVITY
}

\author{
Oleh Harziko
}

\begin{abstract}
PT. Namlea Wood Industries is a company engaged in the wood and forest product industry and the company always strives to maximize the potential possessed by employees, however, conditions What happens is that the development of employee performance shows that there is a decrease in employee performance, the indication is indicated by: there is a decrease in the amount of production produced by employees. This study aims to determine the effect of wages and work discipline on employee productivity at PT Wainibe Wood Industry Namlea. This study uses Ordinal Probit analysis to analyze the final results, the significant influence between the dependent and independent variables. Based on the results of data processing carried out, testing data using the SPSS 16 program the results obtained for the wage variable are 0.060 and for the work discipline variable are 0.003. The significant value possessed by the wage variable is greater than the set standard value, i.e. it should not exceed 0.005 so that the effect of the wage variable on work productivity has no significant effect. Meanwhile, the work discipline variable has a significant effect.
\end{abstract}

Keywords: Wages, Work Discipline, Work Productivity.

\section{INTRODUCTION}

Human resource management (HRM) is a part of organizational management that focuses on the elements of resources man. The task of HRM is to manage the human element well so that obtained workers who are satisfied with their work. Within the organization, human is one of the most important elements. No HRM role though the various factors needed are already available the organization will not run, because humans are the movers and determinants of the running of an organization so that the existence of human resources becomes an important thing in a organization. The problem of human resources is a challenge for management because the success of management and others depends on quality of human resources.

One of the factors that affect the success rate of a company organization is the performance of its employees. Employee performance is a actions taken by employees in carrying out the work given company (Handoko, 2011). Every company always expects employees have achievements, because by having employees who are achievement will provide optimal contribution to the company. Besides Therefore, by having employees who excel the company can increase the company's performance, because companies often face problems regarding human resources. Individuals in the company are human resources owned If it can run effectively, the company will continue to run effectively. With words

On the other hand, the continuity of a company is determined by the performance of its employees. Employee performance can be influenced by several factors, namely: compensation, work environment, organizational culture, leadership and work motivation, discipline work, job satisfaction, communication and other factors (Siagian, 2012). Efforts to improve employee performance, including: provide motivation for employees. In general, people want to work to be able to meet the needs and desires (physical and mental), both conscious needs and unconscious needs. Fulfillment

These needs are the basis of an employee's work motivation. If In the process of meeting these needs, employees feel an opportunity in achieving the goal, the motivation to achieve it will be more doubled due to an increase in employee satisfaction at work (Robbins, 2006:67).

Company through established compensation programs both financial and non-financial compensation are important for observed and implemented in accordance with the provisions. 
Financial compensation provided by the company is related to the provision of salaries or wages, bonuses, incentives and other financial policies. As for when with non-financial policy in terms of this determination in accordance with the ability, good relations between employees and management as well as other policies related to non-financial. Financial and non-financial compensation policies can reflect company's efforts to maintain the resources they have, so that both components prove to be more effective in maintenance workforce to motivate employees in an effort to improve performance that has been achieved by employees in working in the company and the policy is also carried out at PT. Waenibe Wood Industries in efforts employee performance improvement.

PT. Namlea Wood Industries is a company engaged in the wood and forest product industry and the company always strives to maximize the potential possessed by employees, however, conditions What happens is that the development of employee performance shows that there is a decrease in employee performance, the indication is indicated by: there is a decrease in the amount of production produced by employees.

The results of previous research conducted by Julian (2013) obtained The results show that compensation has a significant effect on employee performance. The existence of this influence indicates that with a change in the provision of compensation will affect the achievement of employee performance. The same results are shown from the results of research by Wijaya and Andrean (2015) The results obtained are that compensation has a significant effect on employee performance and Firmandari (2014) also obtained the same results, namely direct effect of compensation on employee performance.

\section{Daftar Pustaka}

Sam, B., Iye, R., Ohoibor, M., Umanailo, M. C. B., Rusdi, M., Rahman, A. B. D., \& Hajar, I. (2019). Female Feminism in the Customary Island of Buru. Int. J. Sci. Technol. Res, 8(8), 1877-1880.

Susiati, S., Iye, R., \& Suherman, L. O. A. (2019). Hot Potatoes Multimedia Applications in Evaluation of Indonesian Learning In SMP Students in Buru District. ELS Journal on Interdisciplinary Studies in Humanities, 2(4), 556-570.

Susiati, S., Iye, R., \& Suherman, L. O. A. (2019). Hot Potatoes Multimedia Applications in Evaluation of Indonesian Learning In SMP Students in Buru District. ELS Journal on Interdisciplinary Studies in Humanities, 2(4), 556-570.

Iye, R., \& Susiati, S. (2018). NILAI EDUKATIF DALAM NOVEL SEBAIT CINTA DI BAWAH LANGIT KAIRO KARYA MAHMUD JAUHARI ALI (Educative Values in Sebait Cinta di Bawah Langit Kairo by Mahmud Jauhari Ali). Sirok Bastra, 6(2), 185-191.

Susiati, S. (2018). Homonim bahasa kepulauan tukang besi dialek kaledupa di kabupaten wakatobi [the homonymon of tukang besi island languange in kaledupa dialect at wakatobi regency]. Totobuang, 6(1), 109. 
Susiati, S. (2020). The Concept Of Togetherness In The Films" Aisyah Biarkan Kami Bersaudara" By Herwin Novianto.

Nurhayati, N., \& Said, I. (2019). Emosi Verbal Suku Bajo Sampela. Sosial Budaya, 16(2), 114126.

Susiati, S., \& Iye, R. (2018). Kajian Geografi Bahasa dan Dialek di Sulawesi Tenggara: Analisis Dialektometri. Gramatika: Jurnal Ilmiah Kebahasaan dan Kesastraan, 6(2), 137-151.

Susiati, S. The Concept Of Togetherness In The Films" Aisyah Biarkan Kami Bersaudara" By Herwin Novianto.

Iye, R., Susiati, S., \& Karim, K. (2020). Citra Perempuan dalam Iklan Sabun Shinzui. Sang Pencerah: Jurnal Ilmiah Universitas Muhammadiyah Buton, 6(1), 1-7.

Susiati, S. (2020). The Concept Of Togetherness In The Films" Aisyah Biarkan Kami Bersaudara" By Herwin Novianto.

Susiati, S. (2020). Eksistensi Manusia Dalam Film" Aisyah Biarkan Kami Bersaudara" Karya Herwin Novianto.

Iye, R. (2018). Tuturan dalam Prosesi Lamaran Pernikahan di Tomia Kabupaten Wakatobi. Jurnal Totobuang, 6(2).

Susiati, S. Konsep Pertentangan Dalam Film" Aisyah Biarkan Kami Bersaudara" Karya Herwin Novianto.

Wael, A., Setiaji, A. B., Pannyiwi, R., Lapandewa, L., Asshagab, S. M. N., Jouhari, B., ... \& Umanailo, B. (2019). „Bupolo“e Motion Reading. Int. J. Sci. Technol. Res, 8(9), 21542158 .

Susiati, S. (2020). Konsep Kebersamaan Dalam Film" Aisyah Biarkan Kami Bersaudara" Karya Herwin Novianto.

Wael, A., Setiaji, A. B., Pannyiwi, R., Lapandewa, L., Asshagab, S. M. N., Jouhari, B., ... \& Umanailo, B. "Bupolo" Motion Reading.

Iye, R. H. (2019). NILAI-NILAI MORAL DALAM TOKOH UTAMA PADA NOVEL SATIN MERAH KARYA BRAHMANTO ANINDITO DAN RIE YANTI. TELAGA BAHASA,(7), 2, 195-206.

Iye, R. Jl Prof Dr HAR Basalamah No, and Namlea-Kab Buru.". TUTURAN DALAM PROSESI LAMARAN PERNIKAHAN DI TOMIA KABUPATEN WAKATOBI." Kontemporer. Bandung: PT Remaja.

Iye, R., Tenriawali, A. Y., Susiati, A., \& Buton, D. (2020). Makna dan Fungsi Emosi Mahasiswa Kota Baubau dalam Ranah Demonstrasi: The Meaning And Emotional Function Of Students Of Baubau City In The Demonstration Plan. Uniqbu Journal of Social Sciences, 1(1), 25-37. 
Referen, B. Konsep teori de Saussure ini dikembangkan lagi oleh Richard dan Ogdent (dalam Chaer, 1994: 287) Dalam sebuah bagan makna berupa segi tiga yang menghubungkan tiga komponen makna, yaitu bentuk, konsep, dan referen. Bagannya adalah sebagai berikut.

Masiri, R., Iye, R., Harziko, H., Malik, S., \& Karim, K. (2020). ERROR ANALYSIS IN STUDENTS'CLASSROOM DISCUSSION AT MTS LKMD WAEMOLI:(Analisis Kesalahan Berbahasa Dalam Diskusi Siswa Kelas VIII MTS LKMD Waemoli). Uniqbu Journal of Social Sciences, 1(2), 56-62.

Susiati, S. (2020). Semantik: Teori Semantik, Relasi Makna, Marked, Dan Unmarked.

Iye, R., Tenriawali, A. Y., Susiati, A., \& Buton, D. (2020). Makna dan Fungsi Emosi Mahasiswa Kota Baubau dalam Ranah Demonstrasi: The Meaning And Emotional Function Of Students Of Baubau City In The Demonstration Plan. Uniqbu Journal of Social Sciences, 1(1), 25-37.

Susiati, S., Masniati, A., \& Iye, R. (2021). Kearifan Lokal Dalam Perilaku Sosial Remaja Di Desa Waimiting Kabupaten Buru. Sang Pencerah: Jurnal Ilmiah Universitas Muhammadiyah Buton, 7(1), 8-23.

Iye, R., Tenriawali, A. Y., Susiati, A., \& Buton, D. (2020). Makna dan Fungsi Emosi Mahasiswa Kota Baubau dalam Ranah Demonstrasi: The Meaning And Emotional Function Of Students Of Baubau City In The Demonstration Plan. Uniqbu Journal of Social Sciences, 1(1), 25-37.

BAUBAU, T. O. FOLLOW THE EVENTS IN THE INDONESIAN LANGUAGE EXPRESSIVE SAID TRANSACTION IN THE TRADITIONAL MARKET.

Iye, R. (2018). Tuturan emosi mahasiswa kota baubau dalam ranah demonstrasi.

Susiati, S., Masniati, A., \& Iye, R. (2021). Kearifan Lokal Dalam Perilaku Sosial Remaja Di Desa Waimiting Kabupaten Buru. Sang Pencerah: Jurnal Ilmiah Universitas Muhammadiyah Buton, 7(1), 8-23.

Susiati, S. Fenomena Tuturan Emosi Verbal Bahasa Indonesia Suku Bajo Sampela.

Iye, Risman, A. Yusdianti Tenriawali, Azwan Susiati, and Darwis Buton. "MAKNA DAN FUNGSI EMOSI MAHASISWA KOTA BAUBAU DALAM RANAH DEMONSTRASI: THE MEANING AND EMOTIONAL FUNCTION OF STUDENTS OF BAUBAU CITY IN THE DEMONSTRATION PLAN." Uniqbu Journal of Social Sciences 1, no. 1 (2020): 25-37.

Harziko, H., Said, I. M., \& Darwis, K. (2018). FOLLOW THE EVENTS IN THE INDONESIAN LANGUAGE EXPRESSIVE SAID TRANSACTION IN THE TRADITIONAL MARKET TOWN OF BAUBAU. JURNAL ILMU BUDAYA, 6(1). 
Susiati, S., Tenriawali, A. Y., Nursin, N., Nacikit, J., \& Mukadar, S. (2020). NILAI EDUKASI DALAM NOVEL PARTIKEL KARYA DEWI LESTARI:(The Value of Education in Particle Novels by Dewi Lestari). Uniqbu Journal of Social Sciences, 1(3), 176-183.

Yusnan, M., Kamasiah, R. I., Karim, H., \& Bugis, R. (2020). Alih Kode dan Campur Kode pada Novel Badai Matahari Andalusia Karya Hary El-parsia: Transfer Code And Mix Code In Novels Badai Matahari Andalusia Karya Hary El-parsia. Uniqbu Journal of Social Sciences, 1(1), 1-12.

Yusnan, M., Kamasiah, R. I., Karim, H., \& Bugis, R. (2020). ALIH KODE DAN CAMPUR KODE PADA NOVEL BADAI MATAHARI ANDALUSIA KARYA HARY ELPARSIA: Transfer code and mix code in Novels Badai Matahari Andalusia Karya Hary El-Parsia. Uniqbu Journal of Social Sciences, 1(1), 1-12.

Iye, R. WRITING SKILLS IN SMP USWATUN HASANAH. BURU DISTRICT.

Karim, A. B., \& Yusnan, M. Aspek Spiritual Dalam Novel Tuhan Izinkan Aku Menjadi Pelacur Karya Muhidin M Dahlan: Spiritual Aspects in the Lovely of God Let Me Become a Property of Muhidin M Dahlan. Uniqbu Journal of Social Sciences, 1(1), 61-71.

Bin-Tahir, S. Z., Suriaman, A., Hanapi, H., Iye, R., \& Umanailo, M. C. B. (2020). Development of Buru Local Language Conversation Material Based on the CommunicativeInteractive Approach for Elementary School Students. Solid State Technology, 63(2s).

Iye, R. WRITING SKILLS IN SMP USWATUN HASANAH. BURU DISTRICT.

Susiati, S., Tenriawali, A. Y., Nursin, N., Nacikit, J., \& Mukadar, S. (2020). NILAI EDUKASI DALAM NOVEL PARTIKEL KARYA DEWI LESTARI:(The Value of Education in Particle Novels by Dewi Lestari). Uniqbu Journal of Social Sciences, 1(3), 176-183.

Karim, A. B., \& Yusnan, M. (2020). Aspek Spiritual Dalam Novel Tuhan Izinkan Aku Menjadi Pelacur Karya Muhidin M Dahlan: Spiritual Aspects in the Lovely of God Let Me Become a Property of Muhidin M Dahlan. Uniqbu Journal of Social Sciences, 1(1), 6171.

Andini, K. NILAI BUDAYA SUKU BAJO SAMPELA DALAM FILM THE MIRROR NEVER LIES KARYA KAMILA ANDINI.

Umanailo, M. C. B., Hentihu, I., Umanailo, R., Nawawi, M., Pulhehe, S., Ohoibor, M., ... \& MANGESA, R. (2018). Comprehension To Village.

Andini, K. NILAI BUDAYA SUKU BAJO SAMPELA DALAM FILM THE MIRROR NEVER LIES KARYA KAMILA ANDINI.

Umanailo, M., Hentihu, I., Umanailo, R., Nawawi, M., Pulhehe, S., Ohoibor, M., ... \& Musa, M. N. D. (2017). Comprehension To Village (No. yuavq). Center for Open Science.

Susiati, S. (2020). Nilai Budaya Suku Bajo Sampela Dalam Film The Mirror Never Lies Karya Kamila Andini. 
Susiati, S., \& Iye, R. (2018). Kajian Geografi Bahasa dan Dialek di Sulawesi Tenggara: Analisis Dialektometri. Gramatika: Jurnal Ilmiah Kebahasaan dan Kesastraan. 6 (2), 137-151.

Rabadia, E. S. O., \& Hanapi, H. STUDENTS'WRITING SKILL THROUGH CLUSTERING TECHNIQUE.

Sam, B., Iye, R., Ohoibor, M., \& Umanailo, M. CB, Rusdi, M., Rahman, ABD, \& Hajar, I.(2019). Female Feminism in the Customary island of Buru, 1877-1880.

Lafamane, F. (2020). Perkembangan Teori Sastra (suatu Pengantar).

Bin Tahir, S. Z., Iye, R., Tenriawali, A. Y., Karim, Z. Z. Z., \& Umanailo, M. C. B. (2020, March). Cia-cia vocational inventoryization in Buru district. In Proceedings of the International Conference on Industrial Engineering and Operations Management (No. 0, pp. 25092518).

Nurlatu, J., Bugis, R. K., Karim, K., Azwan, A., \& Iye, R. (2020). Penggunaan Dieksis Sopan Santun Mahasiswa Universitas Iqra Buru. Jurnal Ilmiah FONEMA: Jurnal Edukasi Bahasa dan Sastra Indonesia, 3(2), 154-164.

Susiati, S. PERWUJUDAN SIMILE OLEH MERARI SIREGAR DALAM NOVEL AZAB DAN SENGSARA.

Susiati, S. Dialektometri Segitiga: Hubungan Kekerabatan Bahasa Di Sulawesi Tenggara (Bahasa Wakatobi, Bahasa Cia-Cia, Bahasa Pancana, Bahasa Kioko, Bahasa Tolaki).

Lafamane, F. (2020). Perkembangan Teori Sastra (suatu Pengantar).

Susiati, S., \& Mufidati, E. (2020). An Indonesian National English Textbook for Secondary Level: Is It Qualified Enough?. Jurnal VARIDIKA, 32(1), 118-124.

Yulismayanti, H., Iye, R., \& Susiati, S. Z. B. T. (2020). VARIATIVE METHOD IN IMPROVING STUDENT LEARNING MOTIVATION IN PANDEMIC COVID-19 SITUATIONS. Journal of Critical Reviews, 7(5), 1584-1595.

Susiati, S. Dialektometri Segitiga: Hubungan Kekerabatan Bahasa Di Sulawesi Tenggara (Bahasa Wakatobi, Bahasa Cia-Cia, Bahasa Pancana, Bahasa Kioko, Bahasa Tolaki).

Yulismayanti, H., Iye, R., \& Susiati, S. Z. B. T. (2020). VARIATIVE METHOD IN IMPROVING STUDENT LEARNING MOTIVATION IN PANDEMIC COVID-19 SITUATIONS. Journal of Critical Reviews, 7(5), 1584-1595.

Lafamane, Felta. "KAJIAN STILISTIKA (Komponen Kajian Stilistika)." (2020).

Susiati, Susiati. "Makian Bahasa Wakatobi Dialek Kaledupa." (2020).

Bassalamah, J. P. D. H. (2020). MAKIAN BAHASA WAKATOBI DIALEK KALEDUPA. 
Susiati, S. risman iye. 2020.“. Dialektometri Segitiga: Hubungan Kekerabatan Bahasa Di Sulawesi Tenggara (bahasa Wakatobi, Bahasa Cia-cia, Bahasa Pancana, Bahasa Kioko, Bahasa Tolaki).” OSF Preprints. July, 21.

Yulismayanti, Y., Harziko, H., \& Irmawati, A. Kemampuan Menemukan Nilai Edukatif Dalam Cerpen Juru Masak Karya Damhuri Muhammad Siswa Kelas X SMA Negeri 12 Buru:(the Avility to Find Educative Values in Story of Master Teacher Work of Damhuri Muhammad at SMP 12 Buru). Uniqbu Journal of Social Sciences, 1(2), 35-48.

Yulismayanti, Y., Harziko, H., \& Irmawati, A. (2020). Kemampuan Menemukan Nilai Edukatif Dalam Cerpen Juru Masak Karya Damhuri Muhammad Siswa Kelas X SMA Negeri 12 Buru:(the Avility to Find Educative Values in Story of Master Teacher Work of Damhuri Muhammad at SMP 12 Buru). Uniqbu Journal of Social Sciences, 1(2), 35-48.

Susiati, S. (2020). Pentingnya Melestarikan Bahasa Daerah.

UNIQBU, P. (2019). TUTURAN EMOSI MAHASISWA KOTA BAU BAU.

Susiati, Y. T. Risman Iye. A. Kesantunan Imperatif Bahasa Indonesia Suku Bajo Sampela: Balai Pembinaan dan Pengembangan Bahasa. 2018. Kongres Bahasa Indonesia (No. 12, pp. 1-6). Report.I

Tenriawali, A. Y., Azwan, R. B., Taufik, M., Harziko, R. I., \& Bin-Tahir, S. Z. Politeness of Language Use amongst Millennial Generation in Namlea City.

Umanailo, M. C. B. (2021). Politeness of Language Use amongst Millennial Generation in Namlea City.

Nurlatu, J., Bugis, R. K., \& Iye, R. Penggunaan Dieksis Sopan Santun Mahasiswa Universitas Iqra Buru.

Hanapi, H. Gaya Bahasa pada Novel Piano dalam Kotak Kaca Karya Agnes Jessica. Uniqbu Journal of Social Sciences, 1(1), 344007. 